\title{
A MODEL FOR DETERMINING THE COMPETITIVENESS OF THE PORTS AND TRAFFIC ROUTES
}

\author{
Mia Jurjević, Čedomir Dundović, Svjetlana Hess
}

Preliminary notes

In order to determine seaports value on a particular geographic area, the research of ports is mainly focused on the performance measurement in accordance with the volume of traffic and productivity on a global scale. As links in the transport and logistics chain, ports are continuously adapting to the demands of customers in international trade to achieve an adequate level of competitiveness. It is necessary and indispensable for the ports of Trieste, Koper and Rijeka to cooperate and join their efforts regarding joint competition with the north-west European and the Black Sea ports. The major objective is to determine which one among the three observed North Adriatic ports, is the most competitive transit port for the selected points of destination in the hinterland, taking into consideration multiple types of cargo. In order to achieve the set objective, in this paper the collective competitiveness index is proposed.

Keywords: competitiveness; competitiveness index; North Adriatic ports; transportation route

Model određivanja konkurentnosti luka i prometnih pravaca

Prethodno priopćenje Istraživanja luka radi utvrđivanja njihove važnosti na pojedinom geografskom području uglavnom su usmjerena na mjerenje performansi u skladu s veličinom prometa i produktivnosti u svjetskim razmjerima. Kao karike u prometnom i logističkom lancu, luke se kontinuirano prilagođavaju zahtjevima korisnika u međunarodnoj robnoj razmjeni radi dostizanja adekvatnog stupnja konkurentnosti. Suradnja luka Trst, Kopar i Rijeka potreba je i nužnost kako bi te luke udruženim snagama zajednički mogle konkurirati sjeverozapadnim europskim i crnomorskim lukama. Cilj je odrediti koja je luka, od tri promatrane sjevernojadranske luke, konkurentnija kao tranzitna luka za odabrane odredišne točke u zaleđu, uzimajući u obzir više vrsta tereta. U radu se za ostvarivanje postavljenog cilja predlaže uvođenje skupnog indeksa konkurentnosti.

Ključne riječi: indeks konkurentnosti; konkurentnost; sjevernojadranske luke; prometni pravac

\section{Introduction}

In the contemporary conditions of the port traffic, the success of ports assumes the fulfilment of typical and atypical customer requirements and the possibility of timely shipment and delivery of various types of goods on different transport routes, using all possible modes of transport.

Due to the constant changes in the port service market such as globalization, development of information technology, high competition and growing customer demands, the improvement of the quality of port services is essential.

As the key link in the transportation chain, sea ports with their tariffs and transport service quality have either a stimulating or destimulating impact upon the acquisition of new cargoes. Sea ports represent a cumulative place in which traffic descends from all the traffic directions and means of transport.

The functioning of the entire cargo flow process within a transport system lies on the assumption that the operation of all the factors involved in the transport chain has been analysed with the aim of bringing them in harmony and obtaining a competitive price and high quality transportation service.

The problem is defined by three different ports that have been competing as transit ports on the same transport route. From the default problem it follows that the subject of the research are three North Adriatic ports, owing to the more or less the same catchment area, then different types of ships arriving at ports and the selected points of destination.

The major objective of this paper is to determine which one among the three observed, is the most competitive transit port for the selected points of destination in the hinterland.

The competitiveness assessment model for ports and their appropriate transportation routes is presented in order to achieve this objective. The setting of the model is shown based on the appropriate data collection and taking into consideration port charges, railway transport charges and transport time.

By applying this model, it is possible to make the computations of the port charge index, railway transport charge index, and railway transport time index.

The introduction of the competitiveness index has also been proposed. The obtained data for each port are compared with the level of competitiveness of another port and based on the results of research the analysis of the competitiveness model results is presented.

The observed model has been tested on the three north Adriatic ports of Rijeka, Koper and Trieste for the following destinations: Vienna, Budapest and Brno.

\section{Competitiveness factor analysis for the ports of Rijeka, Koper, and Trieste}

In setting the competitiveness assessment model, the appropriate data collection, as one of the various preliminary activities, is very important. This paper has the objective to determine which one among the three north Adriatic ports (Rijeka, Koper or Trieste) is the most competitive transit port for the selected points of destination in the hinterland (Vienna in Austria, Budapest in Hungary and Brno in the Czech Republic). Certain types of cargo have been taken into consideration including general cargo, coal and grain carriers. Liquid cargoes have not been considered. 
Where the operation and development of a port are concerned, the national transport related to the foreign trade plays a very important role as the one to be counted upon with certainty and with comparatively precise quantity and structure planning possibilities. Goods in transit represent the non-commodity export producing foreign currency income and attracting significant cargo quantities which make the essential prerequisite for a better port development and port capacity engagement. Therefore, the national substratum does not suffice either for an optimum exploitation of port capacities or for any significant development rate. Thus, the good standing on the international market is highly required as well as struggling for as many commodities as possible from the hinterland countries [1, pp. 197].

The volume of port traffic depends on: geographical position, the size of the catchment area, the size and contemporary of port capacity, infrastructure and suprastructure, development of hub ports (the number of line service), labour organization in the port and port staff expertise and management.

The competitiveness level of ports can be established according to the volume of port traffic. Valuation and competitiveness of each transportation route depends on many different factors such as: geographical position, transport corridors, transport flows, transport infrastructure and suprastructure (port, road, rail), catchment area, competition, transport policy, tariff policy.

Valuation of the transportation route at the port of Rijeka and its competitiveness on the transport market depends on the coordinated action of all transport operators such as:

- maritime operators: port of Rijeka, shipowners, forwarders, shipping agents, light dues companies, pilot companies (pilotage, towage),

- onshore operators: road transport operators, rail transport operators,

- operators for the organization of inland waterways transportation (river-channel transportation).

The criteria of competitiveness for the transportation route can be different in a number of ways. One of the ways is by taking into consideration the so-called "Quality-Price Ratio". Based on the foregoing "Ratio", the two main groups of competitiveness for the transportation route can differ, including [2, pp. 54]: economic criteria and qualitative criteria.

In assessing the competitiveness of a certain transportation route involving hub ports, land communications with the hinterland, as well as the size of the catchment area, both of the mentioned criteria have been used here.

Economic criteria include port costs and expenses and land transport costs, while the time required for transport costs ranks among the qualitative criteria. These factors are considered essential determinants for the selection of an optimum transportation route.

The basic assumption to increase the competitiveness implies the synchronization of quality, speed and cost of all the transportation operators involved in the implementation of transport services [3, pp. 135].
The distance between the port and the point of destination in the hinterland is an essential factor. However, in consideration of the fact that different distances may take different times in dependence on the land infrastructure quality rate, the number of border crossings, land transport means technical features, transport organization, and the like, the distance is often a poor indicator. For this reason, in this paper the time required from/to the port to/from the point of destination in the hinterland is used as the factor relevant for the selection of a transportation route.

Within the narrow catchment area, the ports of Trieste, Koper and Rijeka operate as competitors. All of them gravitate to the same natural hinterland, yet each of them operates on the market with quite a different approach.

The north Adriatic ports, as compared to other Mediterranean ports, present the closest access to the sea to the continental countries of its hinterland, that are economically well developed without their own access to the sea.

The favourable naval route, that excludes more expensive land transport routes, can be reached by navigating to the northern end of the Adriatic, i.e. to its endpoints. This is the natural and shortest transportation route that connects Europe with the Mediterranean and beyond through the Suez Canal towards the majority of countries in Africa and Asia. This advantage of north Adriatic ports becomes increasingly significant, mainly from the perspective of expenses.

The land connections between major industrial and commercial centres in Central Europe and the north Adriatic ports are on average $50 \%$ shorter than connections with the northern European ports.

In advanced circumstances, according to the basic logistical principles ruling on the international transportation market, in the selection of proper transportation routes for cargo destinations, the situation of the north Adriatic ports deeply indented in the European continent as well as their favourable geographic situation have been given secondary importance, as compared to the transport cost and speed.

Two physically different distances may easily become equal in economical terms. It is important to point out that cargo movement and definitions as well as the creation of particular transportation routes have been nowadays determined to a great extent by multinational companies and large owners to suit their own interests.

Constant changes in the international transport system have contributed to the development of an integrated transport concept with the aim of satisfying the customer needs and demands [4, pp. 276].

It is therefore necessary and indispensable for the ports of Trieste, Koper and Rijeka to cooperate and join their efforts regarding joint competition with the northwest European and the Black Sea ports.

The present cooperation between the ports of Trieste, Koper and Rijeka has been felt in their joint promotion as well as in the promotion of the north Adriatic transportation route on international trade markets, yet, there is a need for aggressive joint marketing activities on any actual as well as potential markets. 
The ultimate objective of cooperation between the ports of Rijeka, Koper and Trieste implies a union of north Adriatic port system. Therefore the North Adriatic Ports Association (NAPA) is established which includes the port of Ravenna, the port of Venezia, the port of Trieste, the port of Koper and the port of Rijeka [5].

The five NAPA seaports are located at the northern tip of Adriatic sea, a natural waterway that penetrates deep into the middle of the European continent, thus providing the cheapest naval route from the Far East via Suez to Europe with a distance that is about $2000 \mathrm{~N} \cdot \mathrm{m}$ shorter than other North-European ports. More than 100 million tonnes of water-borne cargo are handled in the NAPA seaports every year. The cargo consists mainly of general cargo, containers, cars, ores and minerals, fossil fuels, chemicals and others types of cargo.

The Association anticipates cooperation in the development of maritime and hinterland connections, visits from cruise lines, environmental protection, safety and information technology. The ports of NAPA will also invest efforts into the coordinated planning of road, rail and maritime infrastructure, as well as the harmonisation of regulations and procedures in the field of port service provision [5].

The factors relevant to determine the competitiveness assessment model for the three observed north Adriatic ports of Rijeka, Koper and Trieste are:

- port charges for a certain type of vessel,

- railway transport charges to the selected point of destination in the hinterland,

- transport time taken from the port to the destination.

The overall port charges include the following categories of expenses [1, pp. 201]: light dues, port dues, pilotage, mooring/unmooring, custom clearance, agency fee, garbage removal, licence fee, bank guarantee, towage, rest.

In publicly open ports the port tariffs are applied consisting of port fees and port dues. Port fees are adopted and publicly announced by the Port Authorities and they comprise [6, art.62]: port dues, demurrage and berthage.

Port dues are charged to vessels carrying out commercial operations, i.e. loading or discharging passengers, goods and vehicles. Inoperative ship berthage is imposed upon vessels using the port for any purpose other than loading or discharging passengers, goods, and vehicles. Berthage fee is imposed on fishing vessels, yachts and fishing, sport and other types of small crafts and floating units.

Port dues are charged to port users with respect to services used in publicly open ports. It is within the Port Authority's competence to determine the maximum amount applicable. Concessionaires carrying out their activities in publicly open ports are required to publicly announce their own port dues applicable for each particular activity or service rendered.

In order to maintain the competitiveness within the port and on the basis of objective circumstances evaluated as indicative of the port non-competitiveness, the Port Authority is entitled to reduce the tariffs either completely or selectively, with respect to the possibility left to the concessionaires of adapting their business operation to such reduced tariffs.

One of the main factors involved in operations of transport companies and in determining the level of competition in the transport market is the price of transport service. The level and structure of freight rate have the impact on the quantity of demand for transport services, on the exploitation capacity and on effects of services performed.

The process of determining the transport tariff is very complex and can be manifested in tariffs formed for a wide range of different types of cargo, purposes and transportation features, that range from vast numbers of various starting points and destinations on different distances [7, pp. 74].

The cost of transport services is formulated regarding the indispensable factors, which commonly affect the terms of transportation. These factors include [8, pp. 65]:

1) the distance of transport,

2) weight of the goods, i.e. the size of transport,

3) the value and type of goods,

4) ratio between gross and net income of labour in transport,

5) utilization of transport capacity,

6) the level of spatial and temporal irregularity of transport,

7) the terms and conditions of exploitation,

8) density and dispersion of the road network,

9) legislative regulations,

10) the political environment.

Within its supply, the shipping agent submits disbursements account (that contains costs of the ship in port) and agency fees to the owner.

Certain vessel charges are fixed (e.g. pilotage, customs clearance, agency fee, bank guarantee), which means that they do not depend on the value of gross vessel tonnage or net vessel tonnage (GT and NT) or the type of cargo. Conversely, particular charges depend on the tonnage of vessel and the type of cargo being transported (e.g. light dues, port charges, mooring or unmooring).

Formal tariffs are not completely reliable and it is necessary to point out that according to the established custom, lower rates are usually negotiated with customers and particularly where long-term agreements are involved, with respect to the demand fluctuation on the port service market. This sort of information is practically unavailable.

In Tab. 1 the comparison of port charges is displayed (in EUR per ton, per net tonnage, and per vessel's gross tonnage) in respect of the following categories of vessels and various services being rendered at the ports of Rijeka, Koper, and Trieste [9]:

- general cargo vessel discharging 3000 metric tons (MT) of a certain general cargo composition (paper, coils, and timber). Vessel's features are: $3119 \mathrm{GT}$ and 1548 NT;

- bulk carrier of 17973 GT and 7056 NT discharging 27000 tons (MT) of grain;

- bulk carrier discharging 130000 tons (MT) of coal; having the following features: $80300 \mathrm{GT}$ and 40300 NT. 
Table 1 Port charges (in EUR) for general cargo vessel (1), bulk (grain) (2) and bulk (coal) carrier (3) in the ports of Rijeka, Koper and Trieste [9, 10, 11]

\begin{tabular}{|c|c|c|c|c|c|c|c|}
\hline \multirow{2}{*}{ Cost type } & Port & \multirow{2}{*}{ RIJEKA } & \multirow{2}{*}{$\%$} & \multirow{2}{*}{ KOPER } & \multirow{2}{*}{$\%$} & \multirow{2}{*}{ TRIESTE } & \multirow{2}{*}{$\%$} \\
\hline & Vessel & & & & & & \\
\hline \multirow{3}{*}{ light dues } & 1 & 1497 & 23,6 & 396 & 7,8 & 876 & 20,2 \\
\hline & 2 & 8627 & 36,2 & 1803 & 11,3 & 3994 & 27,5 \\
\hline & 3 & 38544 & 37,6 & 10294 & 15,3 & 22793 & 55,4 \\
\hline \multirow{3}{*}{ port dues } & 1 & 2310 & 36,5 & 2299 & 45,5 & 62 & 1,4 \\
\hline & 2 & 8640 & 36,3 & 8276 & 52,0 & 62 & 0,4 \\
\hline & 3 & 41600 & 40,6 & 39847 & 59,4 & 62 & 0,2 \\
\hline \multirow{3}{*}{ pilotage } & 1 & 281 & 4,4 & 175 & 3,5 & 254 & 5,9 \\
\hline & 2 & 217 & 0,9 & 295 & 1,9 & 666 & 4,6 \\
\hline & 3 & 758 & 0,7 & 1028 & 1,5 & 1614 & 3,9 \\
\hline \multirow{3}{*}{$\begin{array}{l}\text { mooring / } \\
\text { unmooring }\end{array}$} & 1 & 206 & 3,3 & 173 & 3,4 & 146 & 3,4 \\
\hline & 2 & 1186 & 5,0 & 997 & 6,3 & 409 & 2,8 \\
\hline & 3 & 5299 & 5,2 & 4454 & 6,6 & 769 & 1,9 \\
\hline \multirow{3}{*}{ custom clearance } & 1 & 300 & 4,7 & 219 & 4,3 & 396 & 9,1 \\
\hline & 2 & 300 & 1,3 & 219 & 1,4 & 396 & 2,7 \\
\hline & 3 & 300 & 0,3 & 219 & 0,3 & 396 & 0,9 \\
\hline \multirow{3}{*}{ agency fee } & 1 & 1100 & 17,4 & 828 & 16,4 & 1518 & 35,0 \\
\hline & 2 & 2043 & 8,6 & 1923 & 12,1 & 2832 & 16,5 \\
\hline & 3 & 4123 & 4,0 & 3467 & 5,2 & 4933 & 12,0 \\
\hline \multirow{3}{*}{ garbage removal } & 1 & 107 & 1,7 & 41 & 0,8 & 31 & 0,7 \\
\hline & 2 & 105 & 0,4 & 48 & 0,3 & 52 & 0,4 \\
\hline & 3 & 105 & 0,1 & 53 & 0,1 & 64 & 0,2 \\
\hline \multirow{3}{*}{ licence fee } & 1 & 16 & 0,2 & 77 & 1,5 & / & 1 \\
\hline & 2 & 16 & 0,1 & 95 & 0,6 & 1 & I \\
\hline & 3 & 16 & 0,0 & 109 & 1,2 & I & 1 \\
\hline \multirow{3}{*}{ bank guarantee } & 1 & 50 & 0,8 & 40 & 0,8 & 1 & 1 \\
\hline & 2 & 189 & 0,8 & 125 & 0,8 & 1 & 1 \\
\hline & 3 & 813 & 0,8 & 535 & 0,8 & I & I \\
\hline \multirow{3}{*}{ towage } & 1 & 353 & 5,6 & 657 & 13.0 & 657 & 15,2 \\
\hline & 2 & 2379 & 10,0 & 1970 & 12,4 & 5592 & 38,4 \\
\hline & 3 & 10759 & 10,5 & 6919 & 10,3 & 9982 & 24,3 \\
\hline \multirow{3}{*}{ rest } & 1 & 110 & 1,7 & 146 & 2,9 & 396 & 9,1 \\
\hline & 2 & 110 & 0,5 & 146 & 0,9 & 547 & 3,8 \\
\hline & 3 & 110 & 0,1 & 146 & 0,2 & 547 & 1,3 \\
\hline \multirow{3}{*}{ TOTAL } & 1 & 6330 & 100 & 5051 & 100 & 4336 & 100 \\
\hline & 2 & 23812 & 100 & 15897 & 100 & 14550 & 100 \\
\hline & 3 & 102427 & 100 & 67071 & 100 & 41160 & 100 \\
\hline
\end{tabular}

The port charges for transportation of general cargo, grain and bulk cargo (EUR per vessel gross tonnage) are, for the observed data, computed and presented in Tab. 2, depending on whether the light dues were taken into account or not and according to transportation of different types of cargo at the ports of Rijeka, Koper and Trieste.

Table 2Average port charges for general cargo vessel (1), bulk (grain) carrier (2) and bulk (coal) carrier (3) with and without light dues (EUR/GT) $[9 \div 11]$

\begin{tabular}{|c|c|c|c|c|c|c|}
\hline PORT & \multicolumn{2}{|c|}{ RIJEKA } & \multicolumn{2}{c|}{ KOPER } & \multicolumn{2}{c|}{ TRIESTE } \\
\hline $\begin{array}{c}\text { light } \\
\text { dues }\end{array}$ & with & without & with & without & with & without \\
\hline$(1)$ & 2,03 & 1,55 & 1,62 & 1,49 & 1,39 & 1,11 \\
\hline$(2)$ & 1,32 & 0,84 & 0,89 & 0,78 & 0,81 & 0,59 \\
\hline$(3)$ & 1,28 & 0,79 & 0,84 & 0,71 & 0,51 & 0,23 \\
\hline
\end{tabular}

Observing the port charges for general cargo carrier considering light dues, it can be noticed that the port of Rijeka is in disadvantaged position compared to the port of Koper and Trieste. The port of Rijeka is slightly unfavourable compared to the port of Koper and not competitive according to the port of Trieste, when looking at the same port charges, but without light dues.

Where the port charges for a grain vessel with light dues are concerned, the Rijeka transport route is less competitive than the ports of Koper and Trieste. Taking into account the costs for transportation of grains without light dues, it follows that the port of Rijeka is slightly more unfavourable than the port of Koper and noncompetitive with the port of Trieste.

From the aspect of port charges for a coal vessel with light dues, it can be noticed that the port of Rijeka is unfavourable for this type of transportation. Concerning the port charges for a coal vessel without light dues, it can be observed that the port of Rijeka is slightly unfavourable compared to the port of Koper and noncompetitive according to the port of Trieste.

Based on the derived values above and taking into consideration light dues, it follows that for all the observed types of cargo, i.e. general cargo, grain and coal, Rijeka transport route is not in competition with the port 
of Koper or the port of Trieste. For this reason it can be established that the competitiveness level of the port of Rijeka, as compared to the neighbouring ports of Koper and Trieste, would be much higher if the category of charges concerning light dues were not taken into account.

Observing the level competitiveness of the port of Rijeka and comparing it with the other two North Adriatic ports, taking into account charges without light dues, the following can be concluded.

Since the port of Rijeka is in the present circumstances slightly unfavourable compared to the port of Koper, it can be stated that it could compete with the port of Kopar. According to the analysis of the same types of costs for transportation of general cargo and grain compared to the port of Trieste, the port of Rijeka has more difficulties in achieving its competitiveness, due to much higher charges.

The railway tariff system is a complex system that depends on various factors. The type of cargo is one of important factors that have an impact upon the price of railway transportation $[7, \mathrm{pp} .75]$.

In consideration of the inland (railway) transport charges, it should be noted that transport operators, not being inclined to disrupt their reputation and to impair their development prospects, have consequently made every effort to obtain the freight rates assuring their maximum possible net-returns. On the other hand, transport service users have demanded lower freight rates to be compatible with the transport terms and conditions offered. It can be therefore justifiably argued that the demand for the land transport services on the Rijeka transportation route as well as the size of the port of Rijeka catchment area and turnover will very much depend on the competitiveness of this transportation route as against any other transportation route, in terms of the "inland through transport rates to be borne by the transport service user".

The railway transport charge figures presented in Tab. 3 refer to the public railway tariffs applicable for iron ore, grain and containers from the ports of Rijeka, Koper, and Trieste to the hinterland destinations in Vienna, Budapest, and Brno. The rates are expressed in EUR/ton, in addition to EUR/TEU for containers. Railway transport times from particular ports to the destination have been presented as well.

Table 3 Railway transport rates and time for iron ore, grain, and containers from the ports of Rijeka, Koper, and Trieste to the hinterland destinations in Vienna, Budapest and Brno $[9,10,11]$

\begin{tabular}{|c|c|c|c|c|c|c|c|c|c|c|c|c|}
\hline PORT & \multicolumn{4}{|c|}{ RIJEKA } & \multicolumn{4}{|c|}{ KOPER } & \multicolumn{4}{|c|}{ TRIESTE } \\
\hline DESTINATION & ironore & grain & cont. & $\mathrm{h}$ & ironore & grain & cont. & $\mathrm{h}$ & ironore & grain & cont. & $\mathrm{h}$ \\
\hline Vienna & 1997 & 1539 & 56 & 26 & 1010 & 1439 & 52 & 31 & 809 & 875 & 32 & 18 \\
\hline Budapest & 980 & 980 & 36 & 32 & 1308 & 1308 & 48 & 39 & 1337 & 1449 & 52 & 48 \\
\hline Brno & 1563 & 1563 & 57 & 76 & 1890 & 1890 & 69 & 48 & 1920 & 2032 & 74 & 48 \\
\hline
\end{tabular}

Public railway tariffs often differ from the actually agreed railway tariffs due to various railway freight rebates granted by most railway authorities in different forms and amounts, the majority of them being considered confidential. Taking into account that these rebates cannot be precisely foreseen, being agreed on a case to case basis in dependence on cargo types, cargo quantities, transport user (permanent or temporary) and many other factors, the only possible and justifiable way to carry out the analysis of the railway freight transport tariff component is to use the public railway tariffs in determining the railway transport charge.

\section{Set up of the competitiveness assessment model}

In determining the relevance and competitiveness of ports in a particular geographic area, the researches of ports are mainly focused on measuring the performance in accordance to the size of transport and productivity of ports on a global scale [4, pp. 276].

Prior to setting the model, it should be pointed out that it appears strikingly clear from the data presented in Tab. $1 \div 3$, that the port of Rijeka is not competitive according to its actual light dues figures. The port charges figures are indicative of the seriously jeopardized competitiveness of the port of Rijeka in contrast to the ports of Koper and Trieste, due to the very high light dues level. For this reason, in setting the port of Rijeka competitiveness assessment model, the data are going to be used with this charge included/excluded.
Before model set up it is necessary to carry out a number of various preliminary activities, among which appropriate data collection is very important. Here are the data required:

1) port charges by the category for observed ports,

2) railway transport charges and cargo transport charges to the destination in the hinterland,

3) transport time required from particular ports to particular points of destination.

The requirements for setting the competitiveness assessment model of the port of Rijeka include the comparison of:

- port charges between Rijeka and Koper,

- $\quad$ port charges between Rijeka and Koper for particular vessel types,

- railway transport charges from Rijeka and Koper to the three selected points of destination within the catchment area: Vienna, Budapest and Brno,

- railway transport charges from Rijeka and Trieste to the three selected points of destination within the catchment area: Vienna, Budapest and Brno,

- railway transport times from Rijeka and Koper to the three selected points of destination,

- railway transport times from Rijeka and Trieste to the three selected points of destination.

Based on the above obtained results the model further presents: 
- an individual index table, drawn up so that this relative number may be used in making the above mentioned comparisons,

- the competitiveness index of the port of Rijeka, that is calculated with respect to various cargo types and various hinterland points of destination.

An index is a type of relative number used in comparing two frequencies of the same statistic mass. It indicates the relative change in one frequency as against the frequency it is compared with. The relations between particular phenomena within a group of diversified phenomena can be monitored by individual indexes. Thus, the index is to be used in computing the relations between particular factors of one port as against the other.

By applying this model, it is possible to make the computations (Tab. 4) of:

1) the port charge index,

2) railway transport charge index and

3) railway transport time index.

Table 4 Individual indexes for the competitiveness assessment model

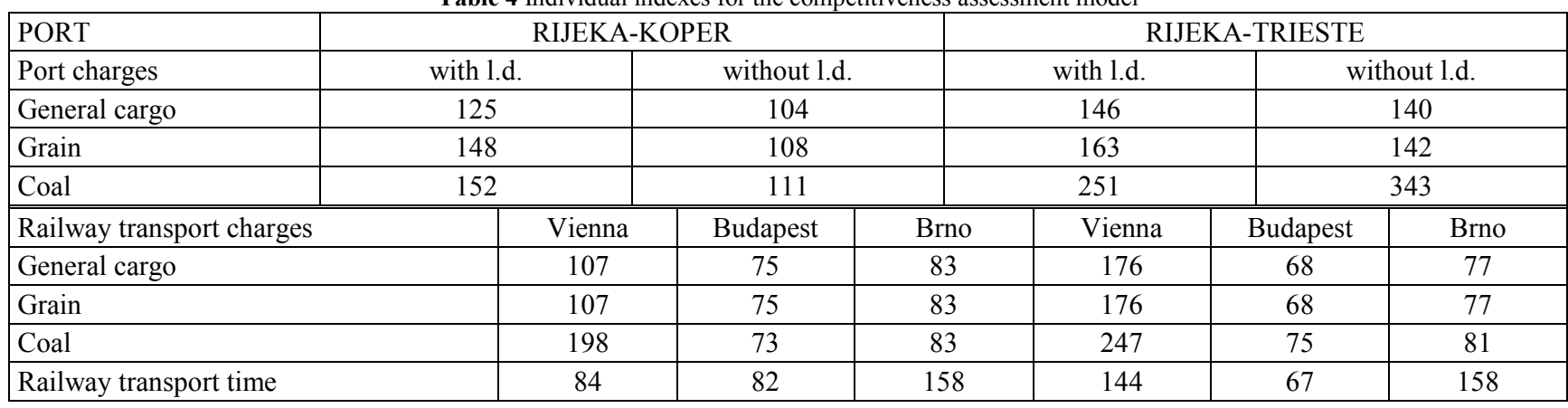

Additional rows and columns can be inserted in Tab. 4 , thus enabling more than the above three factors to be observed as influencing the selection of the transport route. In addition, apart from the three hinterland points of destination, any other point of destination can be selected for cargoes handled in a particular port. Likewise, it is possible to have the competitiveness index computed in respect to additional cargo types, although almost all of them have been comprised with the types already mentioned.

However, no liquid cargoes have been considered, such as oil and oil products, where the port charge indexes can be realistically expected to differ considerably from one port to another. The Table of individual indexes (Tab. 4) is to be used as the basic prerequisite for the competitiveness index computation.

With the aim of assessing the overall competitiveness level for a particular port with respect to various factors (port charges, railway transport charges, transport time) and comparing it to another port competitiveness level or to a competitiveness level expressed in another time unit, the proposal made in this paper refers to the introduction of competitiveness index. It represents the number expressing the relation between the values of factors observed in the port subject to competitiveness assessment and the port compared with, within the time unit observed, for the selected route and cargo type.

The competitiveness index is a collective index obtained as the arithmetic mean of individual indexes (Tab. 5). Collective indexes are numbers used in the measurement of relative changes within a heterogeneous group of phenomena. Typically, the sequence frequencies are expressed in different measurement units or at different value levels.

Table 5 Competitiveness collective index of the port of Rijeka considering the cargo type and its destination with and without light dues

\begin{tabular}{|c|c|c|c|c|c|c|}
\hline with 1.d. & \multicolumn{3}{|c|}{ RIJEKA-KOPER } & \multicolumn{3}{|c|}{ RIJEKA-TRIESTE } \\
\hline Cargo type & Vienna & Budapest & Brno & Vienna & Budapest & Brno \\
\hline General cargo & 105 & 94 & 122 & 155 & 94 & 127 \\
\hline Grain & 113 & 102 & 129 & 161 & 99 & 133 \\
\hline Coal & 145 & 102 & 131 & 214 & 131 & 163 \\
\hline without l.d. & \multicolumn{3}{|c|}{ RIJEKA-KOPER } & \multicolumn{3}{|c|}{ RIJEKA-TRIESTE } \\
\hline Cargo type & Vienna & Budapest & Brno & Vienna & Budapest & Brno \\
\hline General cargo & 98 & 87 & 115 & 153 & 92 & 125 \\
\hline Grain & 99 & 88 & 116 & 154 & 92 & 126 \\
\hline Coal & 131 & 89 & 117 & 245 & 162 & 194 \\
\hline
\end{tabular}

The collective index should be used for a numerical description of a relative change for the whole, whereby the relations between the parts of the whole should be properly manifested. The arithmetic, geometric and harmonic mean values should be applied for the purpose. The choice depends on each particular case, yet the arithmetic mean has been most frequently used. The mentioned mean values can be either pondered or simple.
A simple mean is a good representative of the group value only provided all the phenomena within a group are equally valued, as in the case of this model. Where some of individual indexes are to be particularly emphasized, i.e. attached more value as against the others (e.g. to emphasize the significance of the port charge index within the competitiveness index, as against any other indexes) then the correct relation between the parts and the whole 
is to be pursued by means of the pondered mean. Pondered values are used to emphasize the significance of a phenomenon within a group. A general breakdown of competitiveness indexes for any port, various cargo types and multiple points of inland cargo destination $(D) /$ departure $(D p)$ is shown in Tab. 6.

Table 6 General table for competitiveness index

Table 6 General table for competitiveness index
\begin{tabular}{|l|c|c|c|c|c|c|c|}
\hline PORT I - PORT I & \multicolumn{2}{|c|}{ PORT I - PORT II } & $\ldots$ & \multicolumn{3}{c|}{ PORT I - PORT i } \\
\hline Destination/departure & $D / D p_{I}$ & $\ldots$ & $D / D p_{n}$ & $\ldots$ & $D / D p_{I}$ & $\ldots$ & $D / D p_{n}$ \\
\hline CARGO TYPE & & & & $\ldots$ & & & \\
\hline cargo I & & & & $\ldots$ & & & \\
\hline$\ldots$ & & & & $\ldots$ & & & \\
\hline cargo k & & & & $\ldots$ & & & \\
\hline
\end{tabular}

The above described model may be extended with regard to other charges and some other factors affecting the selection of a particular transport route, additional points of destination within the catchment area of the ports observed and eventually applied to any other ports accordingly.

\section{Result analysis of the competitiveness model}

Analysing the obtained results it can be seen that the port of Rijeka, taking into account the charges for light dues, is in competition with the port of Koper only where transportation of general cargo is concerned, provided that the point of destination or the departure is Budapest.

Compared to the port of Trieste, the port of Rijeka is a more favourable choice with respect to general cargo and grain, provided that the point of destination/departure is Budapest.

However, not taking into account light dues, it can be concluded that the port of Rijeka is in competition with the port of Koper where transportation of general cargo and grains is concerned and if the point of destination/departure is Vienna. Also, the port of Rijeka is more competitive than the port of Koper for transportation of general cargo, grain and coal, when dispatched to Budapest.

The port of Rijeka, where general cargo and grain are concerned, is more competitive in relation to the port of Trieste, when destined to Budapest.

Based on the previous result analysis it can be concluded that the port of Rijeka is in competition with its neighbouring ports only with respect to general cargo and grain destined to Hungary.

The ports of Koper and Rijeka have been primarily focused on the transit of goods, representing in both ports a share of $70 \%$ of the total turnover, whereas the share of transit cargoes in the port of Trieste only amounts to approx. 20\%. The most significant transit routes for the ports of Rijeka and Koper reach from Austria, Hungary, Czech Republic and Slovakia.

With the reduction of light dues, the port of Rijeka might be in competition with the other two observed ports, thus stimulating the vessel and cargo turnover growth at the port and total turnover growth which would reflect upon higher profits for all the subjects involved in the transport of goods, insurance and other activities on the Rijeka transport route. All this would significantly contribute to faster revival of the port of Rijeka and prosperity of the complete trading industries in Croatia.

It is therefore indispensable for light dues to be brought to a competitive level as soon as possible, thus to enable the Rijeka transport route to compete with the other north Adriatic ports under the same conditions. This will open faster possibilities for the comeback of cargoes and shipping lines lost, as well as for the attraction of new ones.

Having in mind that practically the inland transport charge and quality, particularly where railway transport is involved, have considerable impact upon the canvassing of new cargoes, attention should be paid to the canvassing of cargoes in transit from Hungary, the Czech Republic and Slovakia, where railway transport charges are more competitive than those from the neighbouring ports of Koper and Trieste.

\section{Conclusion}

As links in the transportation and logistic chain, sea ports are continuously adjusting to the customer requirements in the international trade, with the aim of achieving an adequate level of competitiveness. Thus new challenges are set for ports, sustained as a result of changes in the port environment and induced by the new terms in the shipping industry, organizational structure, port management and logistics.

Security in providing services is very important for the competitiveness of ports. Inadequate equipment for cargo handling and insufficient competence of the staff for handling the transportation and transhipment services at ports are often limiting factors for reaching an acceptable level of security from the aspect of customers and from the aspect of port.

It is necessary and indispensable for the ports of Trieste, Koper and Rijeka to cooperate and join their efforts regarding joint competition with the north-west European and the Black Sea ports.

The ultimate objective of cooperation between the ports of Rijeka, Koper and Trieste implies a union of north Adriatic port system.

Therefore the North Adriatic Ports Association (NAPA) is established including the following ports: the port of Ravenna, the port of Venezia, the port of Trieste, the port of Koper and the port of Rijeka.

It can be concluded from the competitiveness model presented here regarding the port of Rijeka as compared to the neighbouring ports of Koper and Trieste, attracted by almost the same catchment area, that the competitiveness level of the port of Rijeka would be much higher if the category of charges concerning light dues were not taken into account.

According to the analysis of the data collected, as well as an insight into the competitiveness model results, 
it can be concluded that the port of Rijeka and the Rijeka transport route catchment area cover the territories of the Czech Republic, Slovakia and Hungary, whereas in case of Austria the competitive ports of Trieste and Koper offer more significant advantages.

For this very reason, it is necessary to establish a common administrative body (with the Ministry of Shipping, Transportation, and Infrastructure) to be entrusted with the complete information technology integration and harmonization of all the transport service participants' requirements and objectives. Particular attention should be paid to elimination of "bottlenecks" and impermissibly high disbursements. The basic objective should comprise the determination of the transport service total expenses and quality level required to be competitive on the shipping market and to guarantee the acquisition of new cargoes on the Rijeka transport route.

By applying the observed competitiveness assessment model, the competitiveness index is introduced, that refers to a certain level of competitiveness of the port of Rijeka in relation to the port of Koper and Trieste, according to the certain type of cargo being transhipped and the selected transport route.

The competitiveness assessment model set up in this paper may be extended with regard to other charges and some other factors affecting the selection of a particular transport route, additional points of destination within the catchment area of the ports observed and eventually applied to any other ports accordingly.

\section{References}

[1] Dundović, Č.; Poletan Jugović, T.; Jugović, A.; Hess, S. Integracija i koordinacija lučkog i prometnog sustava Republike Hrvatske. Sveučilište u Rijeci, Pomorski fakultet u Rijeci, Glosa Rijeka, Rijeka, 2006.

[2] Poletan Jugović, T. Struktura preferencije kriterija pri izboru optimalnog prometnog pravca. // Pomorstvo, 20, 2(2006), pp. 47-64

[3] Dundović, Č.; Rudić, D. Morske luke i morsko brodarstvo Primorsko-goranske županije - postojeće stanje I razvojne koncepcije. // Naše more, 52, 3-4(2005), pp. 133-143

[4] Kolanović, I.; Zenzerović, Z.; Skenderović, J. Metodološki pristup empirijskom istraživanju kvalitete lučke usluge. // Pomorstvo, 23, 1(2009), pp. 275-297

[5] URL: http://www.portsofnapa.com/about-napa/. (Jan, 2013)

[6] Zakon o morskim lukama, Narodne novine, 158/03

[7] Baričević, H.; Poletan, T. Tarifna komponenta željezničkog prijevoza kao čimbenik konkurentnosti riječkoga prometnog pravca. // Pomorstvo, 15(2001), pp. 73-84

[8] Baričević, H. Logističke odrednice prometa na kopnu. // Pomorstvo, 14(2000), pp. 63-72

[9] Luka Rijeka d.d., Rijeka, Hrvatska; URL: www.lukarijeka.hr (September, 2013)

[10] URL: www.porto.trieste.it (January, 2014)

[11] URL: www.luka-kp.si (January, 2014)

\section{Authors' addresses}

Mia Jurjević, mag. ing. logist.

Vozišće 12a, HR-51216 Viškovo, Croatia

E-mail: miajurjevicc@gmail.com

Čedomir Dundović, PhD, full professor

Department of Transport Technology and Organization Faculty of Maritime Studies, University of Rijeka

Studentska 2, HR-51000 Rijeka, Croatia

E-mail: dundovic@pfri.hr

Svjetlana Hess, PhD, full professor

Department of Transport Technology and Organization Faculty of Maritime Studies, University of Rijeka Studentska 2, HR-51000 Rijeka, Croatia

E-mail: shess@pfri.hr 